\title{
National Constitutional Courts as Guardians of the Charter: A Comparative Appraisal of the German Federal Constitutional Court's Right to Be Forgotten Judgments
}

\author{
Clara RAUCHEGGER (1)* \\ University of Innsbruck
}

\begin{abstract}
The binding legal force that the Charter acquired with the Treaty of Lisbon has led some national constitutional courts to adopt an entirely new approach to EU fundamental rights. Most notably, the Austrian Constitutional Court, the Italian Constitutional Court, and the German Federal Constitutional Court have explicitly made the Charter a yardstick of constitutional review. This article compares and contrasts the approaches of these three courts to the Charter. It shows that the strategies of the Austrian and German Constitutional Courts have many characteristics in common, including that national constitutional rights are treated as a primary source and the Charter as a mere secondary benchmark in the majority of cases. The most distinctive feature of the Italian Constitutional Court's strategy is that it mainly aims to prevent ordinary courts from circumventing constitutionality refences by directly applying the Charter. The article concludes by arguing that it has many advantages when national constitutional courts adopt the Charter as a yardstick of constitutional review. It is for the constitutional courts and the CJEU to ensure that these benefits are not outweighed by some serious drawbacks of constitutional review in light of the Charter.
\end{abstract}

Keywords: Charter, fundamental rights, constitutional court, constitutional review, Bundesverfassungsgericht, Right to Be Forgotten

\section{INTRODUCTION}

The first three articles of this symposium focused on the impact that the binding Charter of Fundamental Rights of the European Union ('Charter') had on the case law of the Court of Justice of the European Union ('CJEU'). This article turns to the application of the Charter at the Member State level. It demonstrates that the

* Assistant Professor, University of Innsbruck. Supported by the Austrian Science Fund (FWF) [project J 4104-G16]. I am most grateful to Kenneth Armstrong and the anonymous reviewer for their helpful comments. 
binding legal force of the Charter has led some national constitutional courts to adopt an entirely new approach to European Union ('EU') fundamental rights.

Traditionally, most constitutional courts treated EU law as distinct and separate from national constitutional law and readily left its enforcement to the ordinary national courts. ${ }^{1}$ They tolerated that the CJEU gradually strengthened the position of ordinary courts as guardians of EU law through its Simmenthal II line of cases and the preliminary reference procedure. ${ }^{2}$ However, the binding force of the Charter brought about a significant substantive overlap between EU law and national constitutional law. It enhanced the status and visibility of EU fundamental rights so that they are now regularly invoked by right holders and applied by the CJEU and ordinary national courts. ${ }^{3}$ This increase in practical relevance of EU fundamental rights empowers ordinary courts and the CJEU and risks diminishing the eminent position of constitutional courts, which is largely built on their role as ultimate guardians and supreme interpreters of fundamental rights. ${ }^{4}$

The Austrian Constitutional Court was the first one to react to this development by changing profoundly its traditional approach to EU law and creating a special exception in favour of the Charter. It explicitly made the Charter a standard of constitutional review in $2012 .{ }^{5}$ In 2017 and 2019, respectively, the Italian Constitutional Court and the German Federal Constitutional Court followed the example of their Austrian counterpart and embraced the Charter in a series of landmark judgments. This is particularly noteworthy since these two courts are widely known for being very defensive of their national constitutional guarantees. ${ }^{6}$

This article explores the main characteristics of the approaches to the Charter of these three constitutional courts and compares and contrasts them. While the seminal Charter judgments of all three constitutional courts have been given scholarly attention in a number of individual case notes, a comparative analysis of the three approaches is lacking so far. The comparison also helps to explain why constitutional courts can strengthen their position by treating the Charter as a standard of constitutional review.

1 J Komárek, 'The Place of Constitutional Courts in the EU' (2013) 9(3) European Constitutional Law Review 420, p 429.

2 Simmenthal II, 106/77, EU:C:1978:49. For an overview of the development of this case law, see eg A Torres Pérez, 'Challenges for Constitutional Courts as Guardians of Fundamental Rights in the European Union' in $\mathrm{P}$ Popelier et al (eds), The Role of Constitutional Courts in Multilevel Governance (Intersentia, 2013), pp 52-53; M de Visser, 'Juggling Centralized Constitutional Review and EU Primacy in the Domestic Enforcement of the Charter: $A v B$ ' (2015) 52(5) Common Market Law Review 1309, p 1320.

3 See $\operatorname{COM(2019)} 257$ final, 2018 Report on the Application of the EU Charter of Fundamental Rights, pp 14-17.

4 Torres Pérez, note 2 above, pp 49-50; F Schimmelfenning, 'Competition and Community: Constitutional Courts, Rhetorical Action, and the Institutionalization of Human Rights in the European Union' (2006) 13(8) Journal of European Public Policy 1747, p 1251.

5 VfGH, Judgment of 14 March 2012, Charter Judgment, U 466/11 and others.

6 Two examples of this attitude: BVerfG, Judgment of 5 May 2020, PSPP Judgment, 2 BvR 859/15; Corte Costituzionale, Taricco, No 24/2017. 
Part II below examines the German Federal Constitutional Court's two Right to Be Forgotten judgments of 2019 and illustrates why they represented a paradigm shift. ${ }^{7}$ It claims that the German Federal Constitutional Court's previous approach to the Charter was untenable in the long term in light of the wide scope of application that the CJEU has given to the Charter.

Part III compares the German Federal Constitutional Court's approach to the Charter to that of the Austrian Constitutional Court. It shows that the two approaches are more similar than they might seem at first sight. For this reason, a close look at the Austrian Constitutional Court's Charter case law of the past years can give us some indications on the potential future application of the Charter by the German Federal Constitutional Court. The analysis of the case law shows that the Charter is mentioned often, but only rarely given any independent meaning by the Austrian Constitutional Court. It seems likely that the Charter will suffer the same fate in Germany.

Part IV focuses on the Italian Constitutional Court's seminal Charter judgments. It argues that the Italian Constitutional Court had a different aim in mind than its German and Austrian counterparts when it embraced the Charter. The Italian Constitutional Court's main concern was to ensure that it is consulted by ordinary courts when they are faced with a national measure that potentially violates both a domestic constitutional right and the Charter. The reason for this is that in the Italian legal order, unlike in the Austrian and German ones, individuals do not have direct access to the constitutional court. Cases reach the constitutional court via constitutionality references by ordinary courts. If ordinary courts directly apply the Charter to fundamental rights disputes instead of referring to the Italian Constitutional Court, the latter's traditional role as guardian of fundamental rights is at risk of being eroded.

Finally, Part V explores on a more general theoretical level what advantages and disadvantages it can have when national constitutional courts embrace the Charter. It argues that it depends on the attitude of the CJEU and the national constitutional courts whether the many benefits of constitutional review in light of the Charter can outweigh its drawbacks.

\section{THE GERMAN FEDERAL CONSTITUTIONAL COURT'S PARADIGM SHIFT}

In Germany, the binding Charter led to a significant change of the German Federal Constitutional Court's approach to EU fundamental rights. It did not have this effect immediately. After the Charter became binding, the German Federal Constitutional Court treated EU fundamental rights in the same way as it had treated them for the preceding 20 years. The court had established its principal approach to EU fundamental rights in its Solange II judgment of 1986 and maintained it after the Treaty of Lisbon entered into force. ${ }^{8}$ However, in November 2019, shortly before the

7 BVerfG, Judgment of 6 November 2019, Right to Be Forgotten I, 1 BvR 16/13; BVerfG, Judgment of 6 November 2019, Right to Be Forgotten II, 1 BvR 267/17.

8 BVerfG, Judgment of 22 October 1986, Solange II, 2 BvR 197/83. 
ten-year anniversary of the binding Charter, the German Federal Constitutional Court reversed its earlier case law in the two landmark judgments Right to Be Forgotten I and Right to Be Forgotten II. Commentators agreed that this was a ground-breaking paradigm shift that initiated a new era of constitutional fundamental rights protection in Germany. ${ }^{9}$

To understand the significance of the two Right to Be Forgotten judgments, it is necessary to know the German Federal Constitutional Court's previous approach to EU fundamental rights. Section A below therefore examines the German Federal Constitutional Court's traditional separation approach, which was abandoned in 2019. Section B analyses the seminal Right to Be Forgotten judgments.

\section{A. The Traditional Separation Approach}

The German Federal Constitutional Court's traditional approach to EU fundamental rights goes back to the famous Solange II judgment of 1986. In Solange II, the court declared that it would refrain from reviewing EU law for its compliance with the Basic Law, the German Constitution, so long as EU fundamental rights protection remained substantially equivalent to the minimum protection provided by German fundamental rights. ${ }^{10}$ By limiting its own jurisdiction in this way, the German Federal Constitutional Court demonstrated its commitment to the primacy of EU law. ${ }^{11}$

Subsequent case law clarified how the German Federal Constitutional Court dealt with national measures that were determined by EU law. The court distinguished between, on the one hand, national measures that were completely determined by EU law and, on the other hand, those that were only partially determined by EU law because some discretion was left to the Member States. ${ }^{12}$ This approach consisted in a separation between the application of EU and national fundamental rights, which is why it has been termed 'separation thesis' by German legal scholars. ${ }^{13}$

9 D Thym, 'Friendly Takeover, or: the Power of the 'First Word'. The German Constitutional Court Embraces the Charter of Fundamental Rights as a Standard of Domestic Judicial Review' (2020) 16 European Constitutional Law Review 1, p 2; M Wendel, 'Das Bundesverfassungsgericht als Garant der Unionsgrundrechte' (2020) 75(4) JuristenZeitung 157, p 157.

10 Solange II, note 8 above.

11 See BVerfG, Judgment of 15 December 2015, Solange III, 2 BvR 2735/14, para 36.

12 See eg BVerfG, Judgment of 13 March 2007, Emission Allowances, 1 BvF 1/05, para 69; BVerfG, Judgment of 19 July 2011, Le Corbusier, 1 BvR 1916/09, paras 53-54; Solange III, note 11 above, para 39.

13 D Thym, 'Vereinigt die Grundrechte!' (2015) 70(2) JuristenZeitung 53, p 54; C Franzius, 'Grundrechtsschutz in Europa: Zwischen Selbstbehauptungen und Selbstbeschränkungen der Rechtsordnungen und ihrer Gerichte' (2015) 75 Zeitschrift für ausländisches öffentliches Recht und Völkerrecht 383, p 388. For an explanation of the separation thesis in English, see D Thym, 'Separation Versus Fusion: How to Accommodate National Autonomy and the Charter? Diverging Visions of the German Constitutional Court and the European Court of Justice' (2013) 9(3) European Constitutional Law Review 391. 
If a national measure was completely determined by EU law, German fundamental rights had no role to play. National authorities were not obliged to respect them as a consequence of the transferral of competences from Germany to the EU. ${ }^{14}$ Instead, a national measure that was completely determined by EU law was to be reviewed against the standard of the Charter. The German Federal Constitutional Court had no jurisdiction to conduct this review since the Charter did not serve as a standard of constitutional review in Germany. Violations of the Charter were to be claimed before ordinary courts only, ${ }^{15}$ which could refer to the CJEU.

This approach prevented conflicts between EU law and German fundamental rights. Since German fundamental rights did not even apply to national measures that were completely determined by EU law, such conflicts did not arise in the first place and the German Federal Constitutional Court did not have to deal with them. However, the downside of this approach was that the German Federal Constitutional Court did not have any say on national measures that were completely determined by EU law. It had curtailed its own influence by showing respect to the primacy of EU law.

If, on the other hand, a national measure was only partially determined by EU law, the German Federal Constitutional Court considered itself competent to review it, but only against the standard of the Basic Law since the Charter did not serve as a standard of constitutional review. Thus, the Charter played no meaningful role in the case law of the German Federal Constitutional Court, even after it became binding. ${ }^{16}$ In a number of cases, the German Federal Constitutional Court reviewed a national measure solely in light of German fundamental rights, even though the Charter would have been applicable and it was invoked by the claimants. ${ }^{17}$ Judgments that dealt with the Charter in substance either related to horizontal provisions such as Article 51(1) or they were embedded in a particular procedural context, for example, when an individual complaint claimed that an ordinary court's decision not to refer to the CJEU violated the German constitutional right to a lawful judge. ${ }^{18}$

14 Solange III, note 11 above, para 39. See also J Hofmann, 'Grundrechtsschutz durch BVerfG, EuGH und EGMR: Komplementärer, kooperativer und subsidiärer Grundrechtsschutz im Europäischen Rechtsprechungsverbund' in H Rensen and S Brink (eds), Linien der Rechtsprechung des Bundesverfassungsgerichts: Erörtert von den wissenschaftlichen Mitarbeitern (de Gruyter, 2009), p 586; H Sauer, 'Grundrechtskollisionsrecht für das europäische Mehrebenensystem: Konkurrenzbestimmung-Kollisionsvermeidung-Kohärenzsicherung' in N Matz-Lück and M Hong (eds), Grundrechte und Grundfreiheiten im Mehrebenensystem: Konkurrenzen und Interferenzen (Springer, 2011), pp 31-32.

15 M Bäcker, 'Das Grundgesetz als Implementationsgarant der Unionsgrundrechte' (2015) 50(4) Europarecht 389, p 391.

16 J Griebel, 'Doppelstandards des Bundesverfassungsgerichts beim Schutz europäischer Grundrechte' (2013) 52 Der Staat 371, p 383.

17 Ibid, pp 388-89. See eg BVerfG, Judgment of 15 December 2011, 1 BvR 1248/11; Le Corbusier, note 12 above.

18 M Wendel, 'Taking Up the European Mandate: The Charter Before German Courts' in M Bobek and J Prassl (eds), The EU Charter of Fundamental Rights in the Member States (Hart Publishing, forthcoming). 
In extra-judicial writings, some judges of the German Federal Constitutional Court argued that the best interpretation of Article 51(1) of the Charter would be that the Charter is not even applicable to areas of implementing discretion left by EU law. ${ }^{19}$ This neat separation of EU and national fundamental rights would have had the advantage of avoiding complex questions that would arise from their parallel applicability. ${ }^{20}$ Moreover, as Daniel Thym explained, the separation thesis also served to preserve the position of the German Federal Constitutional Court vis-à-vis ordinary courts and the CJEU. The German Federal Constitutional Court willingly renounced having a say on national measures that were completely determined by EU law, but - in turn - it wished to be the ultimate guardian of fundamental rights regarding national measures that were only partially determined by EU law. ${ }^{21}$

However, it is well known that the CJEU opted for a wide scope of application of the Charter, much to the distaste of the German Federal Constitutional Court. ${ }^{22}$ In the view of the CJEU, all national measures that are determined by EU law are bound by the Charter, irrespective of whether the determination is full or partial. ${ }^{23}$ While the degree of determination by EU law does not affect the applicability of the Charter, it has important consequences for the applicability of national fundamental rights within the scope of application of the Charter. Like the German Federal Constitutional Court, the CJEU found that national fundamental rights cannot be applied if a national measure is completely determined by EU law. ${ }^{24}$ If, on the other hand, a national measure is partially determined by EU law, the Member States remain free to apply national fundamental rights in the view of the CJEU, provided that the level of protection of the Charter and the 'primacy, unity and effectiveness of EU law are not thereby compromised'. ${ }^{25}$

Overall, the German separation thesis turned out to be inadequate for protecting the authority of the German Federal Constitutional Court. Under the framework of exclusiveness, a wide scope of application of the Charter automatically reduced the

19 J Masing, 'Einheit und Vielfalt des Europäischen Grundrechtsschutzes' (2015) 70 JuristenZeitung 477, pp 481-82; F Kirchhof, 'Grundrechtsschutz durch europäische und nationale Gerichte' (2011) 64(5) Neue juristische Wochenschrift 3681, p 3684. See also G Britz, 'Grundrechtsschutz durch das Bundesverfassungsgericht und den Europäischen Gerichtshof' (2015) 42 Europäische GrundrechteZeitschrift 275, p 276.

20 Masing, note 19 above, p 484.

21 Thym, note 13 above, pp 406-07.

22 For an analysis of the CJEU's case law on the scope of application of the Charter, see the article by A Torres Pérez in this Symposium. For a stern reaction of the German Federal Constitutional Court to this case law, see BVerfG, Judgment of 24 April 2013, Counter-Terrorism Database, 1 BvR 1215/07.

23 Åkerberg Fransson, C-617/10, EU:C:2013:105, para 29; Melloni, C-399/11, EU:C:2013:107, para 60. See already Wachauf, C-5/88, EU:C:1989:321.

${ }^{24} \mathrm{~V}$ Skouris, 'Développements récents de la protection des droits fondamentaux dans l'Union européenne: Les ârrets Melloni et Åkerberg Fransson' (2013) Il diritto dell'Unione europea 229, p 239. See also M Brkan, 'L'arrêt Melloni: Nouvelle pierre dans la mosaïque de la protection des droits fondamentaux dans l'Union européenne' (2013) 22(1) Revue des affaires européennes 139, p 144.

25 Melloni, note 23 above, para 60. 
influence of domestic fundamental rights and - as a corollary - that of the German Federal Constitutional Court. ${ }^{26}$ In areas of complete determination by EU law, which are continuously expanding, the German Federal Constitutional Court had made itself irrelevant. In addition, the court's hope that it would at least be the sole guardian of fundamental rights regarding national measures that are partially determined by EU law had not materialised. This explains why it found it necessary to revise its previous case law in Right to Be Forgotten I and II.

\section{B. Right to Be Forgotten I and II}

In Right to Be Forgotten I and II, the German Federal Constitutional Court changed its approach to the Charter. ${ }^{27}$ Most importantly, it announced that it would henceforth treat the Charter as a yardstick of constitutional review in addition to German fundamental rights. This is a significant departure from the previous case law. According to Jürgen Kühling, it corresponds to a 'November (r)evolution' ${ }^{28}$

In Right to Be Forgotten II, the national measure at issue was completely determined by EU law. An individual had asked Google to remove a reference to a page containing personal data from the list of search results and had failed before the lower courts. The right to data erasure is fully harmonised by the General Data Protection Regulation ('GDPR'), which meant that the situation was one of complete determination by EU law. ${ }^{29}$ Under its old approach, the German Federal Constitutional Court would have declared itself incompetent to review the case for this reason. However, under the new approach, it did not decline jurisdiction. Instead, it announced that it would review national measures that are fully harmonised by EU law in light of the Charter. ${ }^{30}$ Hence, it adopted the Charter as a direct standard of constitutional review. This is the most significant novelty brought about by the Right to Be Forgotten rulings. ${ }^{31}$

In Right to Be Forgotten I, on the other hand, the national measure at issue was only partially determined by EU law. As in Right to Be Forgotten II, an individual sought to prevent access to personal information online. What distinguished this case from Right to Be Forgotten II was that the claimant had asked the German weekly magazine Der Spiegel to remove a journal article from an online archive maintained by the magazine. According to Article 85(2) GDPR, Member States may lay down exceptions for data processing for journalistic purposes. For this

\footnotetext{
26 D Burchardt, 'Backlash against the Court of Justice of the EU? The Recent Jurisprudence of the German Constitutional Court on EU Fundamental Rights as a Standard of Review' (2020) 21(1) German Law Journal 1, p 10.

27 Right to Be Forgotten I, note 7 above; Right to Be Forgotten II, note 7 above.

28 J Kühling, 'Das "Recht auf Vergessenwerden" vor dem BVerfG: November (r)evolution für die Grundrechtsarchitektur im Mehrebenensystem' (2020) Neue Juristische Wochenschrift 275.

29 Regulation (EU) 2016/679 of the European Parliament and of the Council [2016] OJ L119/1, Art 17.

30 Right to Be Forgotten II, note 7 above, para 53.

31 See also Wendel, note 9 above, p 160; Thym, note 9 above, p 9.
} 
reason, the claimant's request to data erasure was not fully harmonised by EU law. Under its old approach, the German Federal Constitutional Court would have applied German fundamental rights only in this case. Instead, it acknowledged that the Charter could in principle be applied in parallel to German fundamental rights in partial determination scenarios. ${ }^{32}$ Its approach now mirrors that of the CJEU.

Since Right to Be Forgotten I and II, the German Federal Constitutional Court has jurisdiction to review individual complaints regarding all national measures that are determined by EU law. If the national measure is completely determined by EU law, it reviews it in light of the Charter only. If the relevant provision of EU law leaves a degree of implementing discretion to the Member States, both the Charter and national fundamental rights are applicable in parallel.

Regarding the applicability of national fundamental rights to completely determined national measures, the German Federal Constitutional Court maintained the approach that it had developed since Solange II. It did not extend the scope of the Basic Law to national measures that are completely determined by EU law. ${ }^{33}$ In this regard, EU and national fundamental rights are still separated. The novelty was that the German Federal Constitutional Court reclaimed jurisdiction by upgrading the Charter to a direct standard of constitutional review. Therefore, Solange II was not overruled, but complemented by Right to Be Forgotten II. ${ }^{34}$

As mentioned above, the restricted scope of domestic fundamental rights reflects the German Federal Constitutional Court's commitment to the primacy of EU law and thus a pro-European choice. Conflicts between EU law and national fundamental rights are prevented by separating their respective spheres of application. By contrast, the German Federal Constitutional Court's decision to embrace the Charter as a standard of constitutional review might not be as euro-friendly as it seems at first glance. It could potentially lead to an empowerment of the German Federal Constitutional Court vis-à-vis ordinary courts and the CJEU.

The German Federal Constitutional Court's approach to national measures that are partially determined was novel since the court accepted the parallel applicability of EU and national fundamental rights. However, it also announced that German fundamental rights would be the primary standard of review in partial determination scenarios. ${ }^{35}$ This means that the German Federal Constitutional Court and other German courts should primarily apply national fundamental rights to partially determined national measures. ${ }^{36}$ The court emphasised that EU law did not require a uniform standard of fundamental rights protection where it left a degree of implementing discretion to the Member States. ${ }^{37}$ Moreover, it could be presumed

\footnotetext{
32 Right to Be Forgotten I, note 7 above, paras 40-48.

33 Burchardt, note 26 above, p 5.

34 But see Thym, note 9 above, p 14.

35 Right to Be Forgotten I, note 7 above, para 45.

36 Wendel, note 9 above, p 161.

37 Right to Be Forgotten I, note 7 above, para 49.
} 
that domestic fundamental rights provide a level of protection that is equivalent to that of the Charter. ${ }^{38}$

This presumption may be rebutted under two conditions. First, the Charter should be applied when EU secondary legislation specifically prescribes a uniform standard of fundamental rights protection. ${ }^{39}$ Second, the Charter should be applied when one of its rights sets a specific standard that is not provided by domestic fundamental rights protection. ${ }^{40}$ Thus, applicability of national fundamental rights as the primary standard of review does not mean that German fundamental rights generally prevail in a hierarchical sense if the Charter provides for a different standard of protection. ${ }^{41}$ Moreover, even if the presumption is not rebutted and German fundamental rights are applied, the latter are to be interpreted in consistency with the Charter. ${ }^{42}$ It seems that the German Federal Constitutional Court aimed to preserve the German tradition of fundamental rights analyses, while at the same time respecting the requirements set by the CJEU.

The primary applicability of domestic fundamental rights has been criticised by scholars. ${ }^{43}$ There is certainly a danger that the German Federal Constitutional Court merely paid lip service to the applicability of the Charter in partial determination scenarios in these judgments and that it will not actually apply it in practice, even if it would provide for stronger protection. ${ }^{44}$ It is also likely that the German Federal Constitutional Court will classify an EU law measure as partial determination without submitting a preliminary references although the CJEU would qualify it as complete determination. ${ }^{45}$ However, as it was presented in the two judgments, the German Federal Constitutional Court's approach seems to comply with the requirements formulated by the CJEU. In areas of partial determination by EU law, national fundamental rights can be applied, provided that the minimum standard of the Charter and the primacy, unity and effectiveness of EU law are not thereby compromised. $^{46}$

\section{THE AUSTRIAN CONSTITUTIONAL COURT AS A PIONEER}

The German Federal Constitutional Court was not the first constitutional court to upgrade the Charter to a direct standard of constitutional review. It was the Austrian Constitutional Court that had played this pioneering role. Already in 2012, it had delivered its seminal Charter judgment, in which it had found that rights

\footnotetext{
38 Ibid, para 55.

39 Ibid, para 65.

40 Ibid, para 66. For a more detailed explanation of the two scenarios, see Burchardt, note 26 above, p 7.

41 See Thym, note 9 above, p 21.

42 Right to Be Forgotten I, note 7 above, para 60.

43 See eg Burchardt, note 26 above, p 7.

44 See also Wendel, note 9 above, p 165.

45 For an example of this strategy, see Solange III, note 11 above.

46 Melloni, note 23 above, para 60.
} 
granted by the Charter may be considered as rights guaranteed by the Austrian Constitution and can therefore serve as standards of review in constitutional proceedings under certain circumstances. ${ }^{47}$

Section A below distinguishes the Austrian Constitutional Court's approach to the Charter from that of the German Federal Constitutional Court. It demonstrates that the two approaches are more similar than they might seem at first sight. Section B looks at the application of the Charter by the Austrian Constitutional Court since the 2012 Charter judgment was delivered. It concludes that the court primarily applies national fundamental rights to national measures that are partially determined by EU law. The Charter is mentioned often, but it only makes a difference when its Article 47 is used to fill a specific gap left by national fundamental rights protection. The concerns voiced regarding the primary application of national fundamental rights by the German Federal Constitutional Court in partial determination cases have therefore materialised in Austria.

\section{A. Comparison to the German Approach}

The German Federal Constitutional Court created a specific regime for the Charter in its Right to Be Forgotten judgments and did not embrace EU law as a whole. Similarly, the Austrian Constitutional Court created a specific exception to its traditional approach to EU law for the Charter.

EU law traditionally does not serve as a yardstick of review for constitutional adjudication in Austria. ${ }^{48}$ Judicial review regarding EU law is left to the ordinary courts, in the last instance to the Supreme Court and the Supreme Administrative Court. The Austrian Constitutional Court only exercises its jurisdiction with regard to EU law if a breach of EU law is so obvious that it is beyond any reasonable doubt. ${ }^{49}$ However, in the 2012 Charter judgment, the Austrian Constitutional Court reversed this case law with regard to the Charter. It declared that the Charter was a special case in that it could enjoy constitutional status under certain conditions. ${ }^{50}$ The Charter thereby acquired a status in constitutional review proceedings that is similar to the European Convention on Human Rights ('ECHR'), which is part of Austrian constitutional law.

Formally, the Austrian Constitutional Court's incorporation of the Charter differs from that of the German Federal Constitutional Court in its scope. The German Federal Constitutional Court made all rights of the Charter a standard of

47 Charter Judgment, note 5 above.

48 See eg VfGH, Judgment of 8 March 2000, G 23/99; VfGH, Judgment of 12 December 2002, B 1348/02. See also Charter Judgment, note 5 above, II.4.2; VfGH, Judgment of 29 September 2017, G 243/2016 and others, IV.2.3.2; VfGH, Judgment of 4 October 2018, G 132/2018, IV.2.5. Section A draws from C Rauchegger, 'The Charter as a Standard of Constitutional Review in the Member States' in The EU Charter of Fundamental Rights in the Member States, note 18 above.

49 C Grabenwarter and C Pesendorfer, 'Austria: United in Consistent Interpretation' in The EU Charter of Fundamental Rights in the Member States, note 18 above.

50 VfGH, 'National Report', p 3, http://www.confeuconstco.org/reports. 
constitutional review, whereas the Austrian Constitutional Court had only incorporated certain Charter rights. ${ }^{51}$ According to the Austrian Constitutional Court, rights of the Charter need to be equivalent to Austrian constitutional rights in their wording and purpose ('Formulierung und Bestimmtheit') to be recognised as constitutionally guaranteed rights. ${ }^{52}$

It is not necessary that a Charter right overlaps with a domestic right in substance to fulfil this requirement. ${ }^{53}$ However, Charter rights that have a completely different normative structure cannot be treated as constitutionally guaranteed rights. ${ }^{54}$ This entails mainly that Charter principles, as opposed to Charter rights, cannot serve as standards of constitutional review. ${ }^{55}$ Apart from this reservation, the Austrian Constitutional Court does not interpret the requirement of equivalence too restrictively. It has not yet stated that a Charter right falls short of this requirement and it hardly ever examines the equivalence. ${ }^{56}$ Hence, in practice, its approach is not too different from that of the German Federal Constitutional Court.

Regarding the distinction between complete and partial determination by EU law, it is not as prominent in the case law of the Austrian Constitutional Court as in that of its German counterpart, but it exists. In its request for a preliminary ruling and its final judgment in the Digital Rights Ireland case, the Austrian Constitutional Court distinguished between, on the one hand, detailed provisions of EU law which leave no room for implementation that complies with the Austrian Constitution and, on the other hand, EU provisions which leave discretion to the domestic legislator. ${ }^{57}$ This distinction is akin to that of the German Federal Constitutional Court.

In the first scenario, the Charter displaces national fundamental rights. Provisions of national law that essentially transposed provisions of the EU Data Retention Directive $^{58}$ could not be reviewed in light of Austrian fundamental rights because

\footnotetext{
51 Wendel, note 9 above, p 163.

52 Charter Judgment, note 5 above, II.5.5. See also VfGH, Judgment of 12 March 2014, B 166/2013; VfGH, Judgment of 10 October 2018, G 144/2018, IV.B.1.2.1.2. Judge Holoubek of the Austrian Constitutional Court translated 'Bestimmtheit' with 'specific meaning' in an extra-judicial report. VfGH, note 50 above, p 4. Judge Grabenwarter and Christine Pesendorfer translate this term with 'purpose'. Grabenwarter and Pesendorfer, note 49 above.

53 G Baumgartner, 'Grundsätze und Grundrechte der Grundrechte-Charta' in R Feik and R Winkler (eds), Festschrift für Walter Berka (Jan Sramek, 2013), p 12; K Landl-Mraczansky, Die Parallelität des Grundrechtsschutzes: Eine juristisch-abstrakte Analyse aus europa- und verfassungsrechtlicher Sicht mit Blick auf Österreich (PhD Thesis, Johannes Kepler University Linz), p 59.

54 Charter Judgment, note 5 above, II.5.5; B 166/2013, note 52 above.

55 Charter Judgment, note 5 above, II.5.5. See also VfGH, note 50 above, p 4; C Grabenwarter, 'Europäische Grundrechte in der Rechtsprechung des Verfassungsgerichtshofes' (2012) 20 Journal für Rechtspolitik 298, p 301.

56 C Rauchegger, 'The Charter as a Standard of Constitutional Review in the Member States' in The EU Charter of Fundamental Rights in the Member States, note 18 above.

57 VfGH, Judgment of 27 June 2014, Final Ruling Digital Rights Ireland, G 47/12 and others, III.2.2.3-2.2.6.

58 Directive 2006/24/EC of the European Parliament and of the Council [2006] OJ L105/54.
} 
of the EU law principle of primacy. ${ }^{59}$ Accordingly, the Austrian Constitutional Court examined these provisions in light of Article 8 of the Charter, even though the applicants had also invoked the Austrian constitutional right to data protection. ${ }^{60}$ The court noted that the constitutional right of one Member State could not be given priority over the standard of the Charter in a complete determination scenario. ${ }^{61}$

In the second scenario, when EU law leaves a degree of implementing discretion, domestic authorities have to respect both national constitutional rights and the Charter. ${ }^{62}$ The Austrian Constitutional Court applied the Charter and domestic fundamental rights, including ECHR rights, to national measures that fell within the scope of the Data Retention Directive, but were not completely determined by provisions of the Directive. ${ }^{63}$

Thus, like the German Federal Constitutional Court, the Austrian Constitutional Court applies the Charter to national measures that are completely determined by EU law and national fundamental rights and the Charter-in parallel — to national measures that are partially determined by EU law. The main difference between the two courts is that the German Federal Constitutional Court has formulated three conditions to the disapplication of national fundamental rights in complete determination scenarios: the Solange II condition, the constitutional identity condition and the ultra vires condition, which was triggered in the controversial PSPP judgment. ${ }^{64}$ By contrast, the Austrian Constitutional Court has never subjected its acceptance of the primacy of EU law to any conditions derived from national constitutional law. ${ }^{65}$

\section{B. Primary Application of National Fundamental Rights}

A finding of the German Right to Be Forgotten judgments that received criticism finds its equivalent in Austria, although it has not been given much attention in the Austrian academic literature. We have seen above that German fundamental rights will be the primary standard of review for national measures that are partially determined by EU law under the Right to Be Forgotten judgments and that this strategy might not leave much scope for the application of the Charter. ${ }^{66}$ Similarly, the

59 VfGH, Judgment of 28 November 2012, Preliminary Reference Digital Rights Ireland, G 47/12 and others, IV.3.1-3.2; Final Ruling Digital Rights Ireland, note 57 above, III.2.2.4.

60 Preliminary Reference Digital Rights Ireland, note 59 above, IV.4.

61 Ibid, IV.5.2.

${ }^{62}$ See Final Ruling Digital Rights Ireland, note 57 above, II.2.2.4-2.2.6.

63 Ibid, III.2.2.7-2.2.8.

64 PSPP Judgment, note 6 above. For an overview of the three conditions, see C Rauchegger, 'The Bundesverfassungsgericht's Human Dignity Review: Solange III and its Application in Subsequent Case Law' in L Violini and A Baraggia (eds), The Fragmented Landscape of Fundamental Rights Protection in Europe: The Role of Judicial and Non-judicial Actors (Edward Elgar, 2018), pp 97-101.

65 C Grabenwarter, 'National Constitutional Law Relating to the European Union' in A von Bogdandy and J Bast (eds), Principles of European Constitutional Law (Hart Publishing, 2010), p 85.

66 See Section II.B above. 
Austrian Constitutional Court made clear in its 2012 Charter judgment that a case will be decided on the basis of Austrian constitutional law if a Charter right offers the same level of protection ('gleicher Schutzumfang') as a right guaranteed by the Austrian Constitution. ${ }^{67}$

In Austria, the concerns that some commentators have voiced regarding the German approach have indeed materialised. The Austrian Constitutional Court's case law since 2012 demonstrates that this court primarily applies Austrian constitutional rights, including ECHR rights, to national measures that are partially determined by EU law. The Austrian Constitutional Court tends to state as a side note that there is no need to apply the Charter because it does not offer more extensive protection than the equivalent ECHR right or genuinely Austrian constitutional right. Alternatively, it does not comment on the equivalence at all and simply applies the domestic constitutional right after having mentioned the Charter en passant. Overall, the Austrian Constitutional Court only rarely engages in an actual interpretation of the Charter in light of the case law of the CJEU. The Charter has been mentioned in hundreds of cases so far, but it is usually not given much independent meaning.

For example, in several cases involving Article 47 of the Charter (Right to an effective remedy and to a fair trial), the Austrian Constitutional Court assumed or explicitly pronounced that this provision offered the same protection as the corresponding Article 6 ECHR or Article 13 ECHR. ${ }^{68}$ It also treated Article 3 of the First ECHR Protocol (Right to free elections) and Article 39(2) of the Charter (Right to vote and stand as a candidate in municipal elections) as one right. ${ }^{69}$ Furthermore, it indicated that Article 3 (Right to the integrity of the person), Article 4 (Prohibition of torture and inhuman or degrading treatment or punishment), Article 7 (Respect for private and family life), and Article 24 (Rights of the child) of the Charter do not offer more extensive protection than the equivalent ECHR rights. $^{70}$ In other cases, it found that there was no need to apply Articles 15 (Freedom to choose an occupation and right to engage in work) and 16 (Freedom to conduct a business) of the Charter because a provision of the domestic fundamental rights catalogue (Article 6 Staatsgrundgesetz) offered the same protection. ${ }^{71}$ It further merged Article 21 of the Charter (Non-discrimination) with the equivalent domestic constitutional right. $^{72}$

\footnotetext{
67 Charter Judgment, note 5 above. See also VfGH, Judgment of 9 October 2014, G 82/12 and others.

68 Charter Judgment, note 5 above; VfGH, Judgment of 28 November 2013, B 1415/2011; VfGH, Judgment of 25 September 2013, U 1937/2012 and others; VfGH, Judgment of 29 June 2013, B 938/2010; G 144/2018, note 52 above.

69 VfGH, Judgment of 22 August 2014, W I2/2014.

70 VfGH, Judgment of 2 October 2013, U 1815/2013 and others. See also VfGH, Judgment of 13 December 2016, G 494/2015; VfGH, Judgment of 11 December 2019, G 72/2019 and others; VfGH, Judgment of 18 June 2019, G 150/2018 and others.

71 VfGH, Judgment of 2 October 2013, B 1316/2012. See also G 243/2016 and others, note 48 above; G 132/2018, note 48 above.

72 VfGH, Judgment of 12 March 2014, B 803/2013. See also VfGH, Judgment of 12 March 2015, G 205/2014.
} 
However, the Austrian Constitutional Court regularly applied Article 47 of the Charter to supplement domestic constitutional guarantees. For example, it interpreted a provision of national law in the light of Article 47(3) of the Charter, which explicitly provides a right to legal aid for those who lack sufficient resources. ${ }^{73}$ Most often, Article 47(2) of the Charter is used to extend the protection of Article 6(1) ECHR beyond disputes relating to civil rights and obligations and to criminal charges. ${ }^{74}$ In particular, the Austrian Constitutional Court used this Charter provision to extend the guarantees of Article 6(1) ECHR to asylum procedures. ${ }^{75}$ It often assessed the decision of another court not to organise a public hearing in an asylum procedure against Article 47(2) of the Charter. ${ }^{76}$ The parties in asylum procedures do not have a right to a public hearing under Austrian constitutional law as Article 6(1) ECHR is not applicable and genuinely Austrian constitutional law does not enshrine such a right either. The Austrian Constitutional Court therefore combined the domestic fundamental rights guarantees with the Charter and strengthened the fundamental rights protection of individuals by filling a gap left by national constitutional law.

To sum up, the Austrian Constitutional Court mentions the Charter often, but most references to the Charter are nothing more than mere name-dropping. The Charter is only given actual meaning when its Article 47 is used to fill specific gaps in fundamental rights protection that are left by the ECHR and genuinely Austrian constitutional rights. It remains to be seen under what circumstances the German Federal Constitutional Court will apply the Charter in partial determination scenarios. In Right to Be Forgotten, it announced that it will only apply the Charter if EU secondary legislation prescribes a uniform standard of fundamental rights protection or if the Charter offers better protection than the equivalent national right. ${ }^{77}$

\section{THE ITALIAN CONSTITUTIONAL COURT'S ATTEMPT TO PRESERVE CENTRALISED CONSTITUTIONAL REVIEW}

Another constitutional court that has followed the example of the Austrian Constitutional Court is the Italian Constitutional Court. ${ }^{78}$ It embraced the Charter in a seminal judgment of 2017 (No 269/2017). Like its German and Austrian

73 VfGH, Judgment of 26 June 2020, G 302/2019.

74 First case: Charter Judgment, note 5 above. Further examples: VfGH, Judgment of 20 February 2015, E 155/2014; VfGH, Judgment of 23 February 2015, E 155/2014; VfGH, Judgment of 12 June 2015, U1099/2013 and others.

75 Charter Judgment, note 5 above; U 1937/2012, note 68 above.

76 Some examples: VfGH, Judgment of 19 September 2014, U 634/2013 and others; VfGH, Judgment of 5 March 2014, U 2553/2013; VfGH, Judgment of 23 September 2019, E 1494/2019; VfGH, Judgment of 27 November 2019, E 2522/2018; VfGH, Judgment of 24 February 2020, E 3429/2019; VfGH, Judgment of 22 September 2020, E 1453/2020.

77 See Section II.B above.

78 Corte Costituzionale, No 269/2017, 5.2. Part IV draws from C Rauchegger, 'The Charter as a Standard of Constitutional Review in the Member States' in The EU Charter of Fundamental Rights in the Member States, note 18 above. 
counterparts, it announced that it will review national measures that are determined by EU law in light of both the Italian Constitution and the Charter ('in light of internal parameters and, potentially, European ones as well'). ${ }^{79}$ This seems to indicate that Italian constitutional rights will be applied primarily, as in Germany and Austria.

However, there are three important differences to the Austrian and German approaches. First, the Italian Constitutional Court did not need to upgrade the Charter to a standard of constitutional review. EU law has traditionally been a formal yardstick of constitutional review in Italy. ${ }^{80}$ Second, the Italian Constitutional Court did not formally distinguish between complete and partial determination of national measures by EU law. Finally, and most importantly, the Italian Constitutional Court's main concern was to ensure that it is consulted by ordinary Italian courts via constitutionality references when they are faced with a national measure that potentially violates both domestic constitutional rights and the Charter. This part of the article will focus on this most distinctive feature of the Italian Constitutional Court's approach.

The Italian Constitutional Court pursued a different goal than its German counterpart in its 2017 Charter judgment. Its main concern was to strengthen domestic constitutionality references. In contrast to the Austrian and German one, the Italian legal order does not provide for individual constitutional complaints. Constitutionality references by ordinary courts are the main route of access to the Italian Constitutional Court. ${ }^{81} \mathrm{~A}$ domestic procedure of preliminary constitutionality references entails that ordinary courts which have doubts as to whether a statute relevant to a case pending before them is compatible with constitutional law have to stay proceedings and refer the matter to the constitutional court. ${ }^{82}$

The increasing importance of the Charter might have adverse consequences on the constitutionality reference procedure. When ordinary courts are faced with domestic legislation that violates both the domestic constitution and the Charter, they will immediately disapply this legislation on the basis of the EU law principle of primacy. According to the CJEU's Simmenthal II case law, every national court is itself obliged to disregard national law that conflicts with EU law, irrespective of the national model of constitutional adjudication. ${ }^{83}$ As a result of this disapplication of the national legislation, the conflict at issue is resolved and the case might therefore never reach the national constitutional court. The position of ordinary courts is

\footnotetext{
79 Ibid. Translation provided by the Court.

80 D Paris, 'Constitutional Courts as European Union Courts' (2017) 24(6) Maastricht Journal of European and Comparative Law 792, p 801.

81 Ibid, p 802.

82 See M de Visser, Constitutional Review in Europe: A Comparative Analysis (Hart Publishing, 2014), p 132.

83 Simmenthal II, note 2 above, para 21; M Claes, The National Courts' Mandate in the European Constitution (Hart Publishing, 2006), pp 101-02; Torres Pérez, note 2 above, p 51. For a short summary of the case: Komárek, note 1 above, p 428.
} 
strengthened, whereas the constitutional court's traditional role as guardian of fundamental rights is diminished.

Indeed, in Italy, the principle of primacy prevented ordinary courts from referring conflicts between national legislation and EU law to the Italian Constitutional Court. The reason for this was that ordinary courts can only refer to the Italian Constitutional Court when they actually have to apply the contested measure in a concrete case. As soon as the national measure has been disapplied for violation of EU law, the national court does not have to apply it any longer and cannot refer it to the Italian Constitutional Court for this reason. ${ }^{84}$

In its 2017 Charter judgment, the Italian Constitutional Court attempted to re-establish its jurisdiction in these kinds of cases. It declared that all Italian courts must raise questions of constitutionality in disputes that give rise to both questions of constitutionality and questions of compliance with the Charter ('doppia pregiudizialità'). ${ }^{85}$ A subsequent judgment of the Italian Constitutional Court (No 20/2019) confirmed that ordinary courts were obliged to refer to the Italian Constitutional Court in cases of doppia pregiudizialità. ${ }^{86}$ In the view of the Italian Constitutional Court, it was legitimate that it had the first word on these cases. ${ }^{87}$ Its opportunity to intervene with erga omnes effect had to be preserved. ${ }^{88}$

However, in a third judgment, the Italian Constitutional Court did not state explicitly that ordinary courts were obliged to submit a question of constitutionality in cases of doppia pregiudizialità. It only emphasised that it had jurisdiction to examine national measures in light of both the Italian Constitution and the Charter. ${ }^{89}$ This could mean that ordinary courts are free to decide whether they immediately disapply the national measure or refer to the Italian Constitutional Court. In any case, they are no longer prevented from referring to the Italian Constitutional Court in cases of doppia pregiudizialità.

While the Italian Constitutional Court was mainly interested in permitting or even obliging ordinary courts to refer constitutionality questions, the German Federal Constitutional Court did not have this goal in mind in its Right to Be Forgotten judgments. A procedure for preliminary constitutionality references by ordinary courts exists in Germany, but it does not have the same importance as in Italy, since most cases reach the German Federal Constitutional Court through individual complaints. It is even unclear whether the Right to Be Forgotten judgments empower ordinary courts to consult the German Federal Constitutional Court regarding the

\footnotetext{
84 Paris, note 80 above, p 802.

85 Corte Costituzionale, No 269/2017, note 78 above, 5.2. See also G Martinico and G Repetto, 'Fundamental Rights and Constitutional Duels in Europe: An Italian Perspective on Case 269/2017 of the Italian Constitutional Court and Its Aftermath' (2019) 15(4) European Constitutional Law Review 731, p 733.

86 Corte Costituzionale, No 20/2019, 2.1; S Sciarra and AJ Golia, 'Italy: New Frontiers and Further Developments' in The EU Charter of Fundamental Rights in the Member States, note 18 above.

87 Corte Costituzionale, No 20/2019, note 86 above, 2.3 .

88 Ibid, 2.1.

${ }^{89}$ Corte Costituzionale, No 63/2019, 4.3; Martinico and Repetto, note 85 above, p 738.
} 
compatibility of national legislation with the Charter since these judgments concerned complaints by individuals only. ${ }^{90}$

Likewise, the 2012 Charter judgment of the Austrian Constitutional Court concerned individual complaints. However, the Austrian Constitutional Court also clarified that Charter rights constitute yardsticks for reviewing the validity of legislation in the framework of the relevant constitutional review procedures. ${ }^{91}$ This seems to entail that ordinary courts can refer domestic legislation to the Austrian Constitutional Court, even if this legislation would (potentially) need to be disapplied for violation of EU law. ${ }^{92}$ Thus, it seems that the Austrian Constitutional Court ensured the admissibility of domestic constitutionality references, similarly to the Italian Constitutional Court. Yet, since the Austrian Constitutional Court did not do this explicitly in its Charter judgment, it seems that strengthening domestic constitutionality references was not its main interest.

As in Italy, it is not entirely clear in Austria whether ordinary courts are obliged to raise constitutionality questions in these cases. The 2012 Charter judgment can be interpreted in two ways. According to the first reading, the decision can be interpreted as imposing an obligation on ordinary courts to address a constitutionality reference to the Austrian Constitutional Court when they are faced with a statute they deem incompatible with the Charter. ${ }^{93}$ Under the second interpretation, ordinary courts are allowed to choose between referring the impugned national legislation to the Austrian Constitutional Court and directly disapplying it on the basis of the Charter. ${ }^{94}$ Ordinary courts would remain free to directly disapply statutes which violate Charter rights without consulting the Austrian Constitutional Court. ${ }^{95}$ The other two Austrian apex courts seem to adhere to this interpretation since they have openly embraced their role as guardians of the Charter-compatibility of national legislation. ${ }^{96}$

\footnotetext{
90 Thym, note 9 above, p 12.

91 Charter Judgment, note 5 above; G 144/2018, note 52 above, IV.B.1.2.1.2.

92 G 144/2018, note 52 above, IV.B.1.2.1.3; Landl-Mraczansky, note 53 above, pp 66-68. But see M Pöschl, 'Verfassungsgerichtsbarkeit nach Lissabon: Anmerkungen zum Charta-Erkenntnis des VfGH' (2012) Zeitschrift für öffentliches Recht 587, p 604.

93 G Granner, 'Grundrechtecharta und Verfassungsgerichtsbarkeit' in A Kahl et al (eds), Grundsatzfragen der europäischen Grundrechtecharta (Verlag Österreich, 2013), p 36.

94 See D Paris, 'Constitutional Courts as Guardians of EU Fundamental Rights? Centralised Judicial Review of Legislation and the Charter of Fundamental Rights of the EU: $A v$ ' ' (2015) 11 European Constitutional Law Review 389, p 398.

95 L Khakzadeh-Leiler, 'Der Grundrechtsschutz durch den OGH' in K Pabel and N Raschauer (eds), Die Organisation des Grundrechtsschutzes: Nationale und europäische Perspektiven (Verlag Österreich, 2014), p 44.

96 A search in the online legal information system of the Austrian government (RIS) shows that these two courts refer to the Charter on a daily basis.
} 


\section{ADVANTAGES AND DRAWBACKS OF CONSTITUTIONAL REVIEW ON THE BASIS OF THE CHARTER}

Parts II, III, and IV examined the approaches of the German, Austrian, and Italian Constitutional Courts to the Charter and identified commonalities and differences. This Part explores advantages and disadvantages of constitutional review in light of the Charter from a more general theoretical perspective.

Under the EU law principle of procedural autonomy, the national enforcement of the rights of the Charter can be determined by Member States themselves, which may decide to entrust it to the ordinary courts rather than the constitutional court. However, a number of reasons argue in favour of adopting the Charter as a standard of constitutional review. These benefits could outweigh the disadvantages that the application of the Charter by constitutional courts could bring about in practice. It is for the constitutional courts and the CJEU to ensure that this is so.

First, it is not practicable to dissect national measures that are determined by EU law neatly into their EU and their national elements and to assign their review in light of the Charter and their review in light of national fundamental rights to the ordinary and the constitutional judiciary respectively. It makes more sense that the same measure is reviewed in light of EU and national fundamental rights by the same court. By accepting the Charter as a standard of constitutional review, constitutional courts get the opportunity to conduct this comprehensive review.

Moreover, the Austrian and Italian Constitutional Courts rightly emphasised that Charter rights fulfil the same function as national fundamental rights and that they overlap in substance to some extent. ${ }^{97}$ Although national and EU fundamental rights belong to different legal orders, what they have in common is that they are fundamental rights. They fulfil the same function of protecting the basic human rights of individuals from encroachment by public (and sometimes private) authorities. Moreover, as acknowledged by the German Federal Constitutional Court, Charter rights were drawn from the common constitutional traditions of the Member States and the ECHR which still guide their interpretation. ${ }^{98}$ Due to this common core, it would be artificial to separate the application of $\mathrm{EU}$ and national fundamental rights procedurally.

In contrast to what has been claimed by Jan Komárek, the parallel application of EU and national fundamental rights by constitutional courts does not necessarily imply on a conceptual level that the two sets of rights are essentially identical. ${ }^{99}$ Komárek rightly postulated that 'fundamental rights are inherently tied to a particular legal system'. ${ }^{100}$ However, national measures that are determined by EU law are part of both the EU and the respective national legal order. Therefore, both the

97 Charter Judgment, note 5 above; Corte Costituzionale, No 269/2017, note 78 above.

98 See Right to Be Forgotten I, note 7 above.

99 See J Komárek, 'Why National Constitutional Courts Should Not Embrace EU Fundamental Rights' in S de Vries et al (eds), The EU Charter of Fundamental Rights as a Binding Instrument: Five Years Old and Growing (Hart Publishing, 2015), pp 82-88.

100 Ibid, p 84. 
fundamental rights tied to the EU legal order as well as the fundamental rights tied to the national legal order are applicable in parallel. In theory, when Charter rights are taken into account by constitutional courts in their review for violations of domestic fundamental rights, the two sets of rights protection are not treated as identical; they are merely applied in parallel. Like ordinary court judges, constitutional court judges can wear two hats simultaneously. They can be judges of EU law and judges of national law at the same time.

However, in practice, the parallel application of EU and national fundamental rights by constitutional courts can indeed create the impression that the two are identical. This is what happened in Austria, where the Austrian Constitutional Court mostly mentioned the Charter without giving it any independent meaning so far. ${ }^{101}$ This enforced identity is problematic since the Charter is the EU's own bill of rights which is to be distinguished from the fundamental rights catalogues of its Member States.

In a similar vein, it depends on the treatment of the Charter in practice whether its adoption by constitutional courts can enhance the visibility of EU fundamental rights. If the Charter serves as a standard of constitutional review, lawyers and the general public could become more aware of the benefits of claiming violations of Charter rights. ${ }^{102}$ The visibility of the Charter would particularly be increased in Member States in which judgments of the constitutional court are more accessible than judgments of the highest ordinary courts, as it is the case in Belgium. However, the adoption of the Charter by constitutional courts will not have this effect if the Charter is mentioned without being given any independent meaning and in the absence of any engagement with the case law of the CJEU.

If the Charter is taken seriously, the co-application of EU and national fundamental rights by the domestic constitutional court could serve as authoritative guidance for ordinary courts. In particular, constitutional courts can clarify the overlaps and differences between specific national fundamental rights and their counterparts in the Charter. Further, they could develop a co-application approach that can be used as a model by ordinary courts. The consistency of fundamental rights protection within the national legal order would therefore be increased.

Due to the merits of centralised constitutional adjudication, it is important that the approach to the co-application of EU and national fundamentals right of the respective Member State is developed by the domestic constitutional court and not by the supreme or supreme administrative courts. Jan Komárek has identified five arguments in favour of centralised constitutional adjudication. ${ }^{103}$ The first reason to preserve centralised constitutional adjudication is that constitutional courts have more time and resources to engage in constitutional discourses. The second reason is that other institutions tend to be given proper voice and representation in the procedures before constitutional courts. Third, it is relevant that the case law of

\footnotetext{
101 See Section III.B above.

102 See de Visser, note 2 above, pp 1334-35.

103 Komárek, note 99 above, pp 81-82.
} 
constitutional courts attracts adequate attention from the general public. Fourth, the composition of constitutional courts may be marked by greater professional diversity. Constitutional courts tend to not be composed only of lawyers or career judges, as most continental European ordinary courts.

Another value of the co-application of EU and national fundamental rights by constitutional courts is that it can promote the direct cooperation between the CJEU and constitutional courts. If the Charter is not relevant in the constitutional review procedure, constitutional courts do not get the chance to refer preliminary questions on the Charter to the CJEU. If, on the other hand, constitutional courts are responsible for the application of the Charter, they can ask the CJEU to interpret the rights enshrined therein.

Preliminary references could be an ideal avenue for constitutional courts to communicate the meaning of national fundamental rights to the CJEU so that the latter can take it into account when interpreting Charter rights. In line with Article 52(4) of the Charter, the CJEU needs to interpret Charter rights in harmony with the national constitutional traditions from which they derive. If the CJEU takes the constitutional court's interpretation of the domestic right into account, the standard of the Charter would be adapted to the national standard of fundamental rights protection. This could be beneficial to the entire EU since national constitutional courts, as opposed to the CJEU, have a longstanding expertise in fundamental rights adjudication.

Yet, there is a real risk that the CJEU might not engage with the arguments brought forward by the constitutional court and that it could opt for a standard of fundamental rights protection that offers less protection to the right holder. ${ }^{104}$ Besides, Jan Komárek has argued that, on an institutional level, national constitutional courts have nothing to gain in this regard, as making preliminary references in fundamental rights cases increases the influence of the CJEU to their detriment. ${ }^{105}$ It all depends on whether the CJEU is willing to listen to the national constitutional courts. The CJEU's judgment in MAS (Taricco 2) can be seen as a sign of good will in this regard. ${ }^{106}$ However, it should not be overlooked that the Italian Constitutional Court had to threaten to trigger its 'counter-limits' safeguard to convince the CJEU in this case. ${ }^{107}$

Finally, in Member States that do not have a fundamental rights catalogue that is as modern and comprehensive as the Charter, gaps in national fundamental rights protection could be filled by the Charter. The Charter contains a number of more modern fundamental rights that are not explicitly recognised by all the relatively older national fundamental rights catalogues or by the ECHR. We have seen above that the Austrian Constitutional Court has used Article 47 of the Charter to complement

\footnotetext{
104 See eg Melloni, note 23 above.

105 Komárek, note 99 above, p 76.

106 MAS, C-42/17, EU:C:2017:936.

107 Taricco, note 6 above.
} 
domestic constitutional guarantees. ${ }^{108}$ In this way, the application of the Charter by national constitutional courts could be beneficial for right holders.

\section{CONCLUSION}

This article demonstrated that the binding legal force that the Charter acquired with the Treaty of Lisbon has had a profound effect on the approaches of the German, Austrian, and Italian Constitutional Courts to EU fundamental rights. The German and Austrian Constitutional Courts abandoned their previous approaches to EU law with regard to the Charter and made the latter a direct standard of constitutional review. The Italian Constitutional Court did not need to upgrade the Charter to a benchmark of constitutional review since the enforcement of EU law traditionally fell within its jurisdiction. However, it strove to overcome a procedural hurdle that hindered it from reviewing Charter cases due to the Simmenthal II principle. What all three courts have in common is that they attempted to preserve their eminent position as guardians and supreme interpreters of fundamental rights while showing respect to the requirements resulting from EU law.

The analysis also showed that the landmark Charter judgments of the Austrian and Italian Constitutional Courts turned out to be less ground-breaking in the subsequent judicial practice than they seemed at first sight. The Austrian Constitutional Court announced that it would apply the Charter as a standard of constitutional review, but in practice it usually mentions it without giving it any independent meaning. It draws on the Charter only when it uses its Article 47 to be able to apply Article 6 ECHR to asylum procedures. The Italian Constitutional Court declared in its Charter judgment that ordinary courts are required to submit constitutionality questions when they are faced with a national statute that could violate both national constitutional rights and the Charter. However, it seems to have taken back parts of this bold claim in a subsequent judgment so that ordinary Italian courts can now decide whether they want to address the Constitutional Court in such cases or not. It remains to be seen how the famous Right to Be Forgotten judgments will play out in the judicial practice of the German Federal Constitutional Court.

108 See Section III.B above. 